\title{
Micro and Nano Plastics: A Consumer Perception Study on the Environment, Food Safety Threat and Control Systems
}

\author{
Delia Ojinnaka* and Mame Marie Aw \\ School of Applied Sciences, London South Bank University, London, UK
}

Corresponding author: Delia Ojinnaka, School of Applied Sciences, London South Bank University, 103 Borough Road, London UK, SE1 0AA

\section{ARTICLE INFO}

Received: 幽 October 07, 2020

Published: October 15, 2020

Citation: Delia Ojinnaka, Mame Marie Aw. Micro and Nano Plastics: A Consumer Perception Study on the Environment, Food Safety Threat and Control Systems. Biomed J Sci \& Tech Res 31(2)-2020. BJSTR. MS.ID.005064.

Keywords: Micro and Nano Plastics; Food safety; Environmental pollution; Consumer awareness; Control systems

\section{ABSTRACT}

The ubiquitous nature and regular occurrence of microplastics and nanoplastics in the food chain and environment have made them topical subject for investigations. The subject is widely researched but a small group study focusing on ethnic black British is sparse. Thus, the paper aimed to assess the consumers' perception of the control system, environmental and food safety threats of micro- nanoplastics through a critical review and an online survey restricted to the mentioned demography. The review and focus group survey with 72 respondents, demonstrated a general awareness of the environmental detriments of plastics, microplastics and nanoplastics but not the food safety threat. Reduction of the use of plastics, especially single use plastics was overwhelmingly supported, with over $80 \%$ being in favour, In all cases, the standard deviation was low and the coefficient of variation is less than one $(\mathrm{CV}>=1)$. Awareness studies remain key driver to consumer's perception.

\section{Introduction}

Global attention to plastics and subsequently microplastics is growing exponentially as they are ubiquitous, even in very remote regions of the world where people would not think that plastic debris could reach [1]. The environmental impact of microplastics and nano plastics, plus their presence in the food chain have been widely researched $[2,6]$. It has been widely suggested that the threat to food safety and the adverse effects on human health need to be explored further $[6,7,9]$. Additionally, there is no legal classification of microplastics and nano plastics as food contaminants $[4,10]$. The European Food Safety Authority (EFSA) in its 2016 paper on the presence of microplastics and nano plastics in food and seafood, had emphasised the fact that there is not a standard or internationally set definition for both materials. However, microplastics have been defined as a mixture of particles of various shapes such as beads, pellets, fibres, fragments, flakes, granules or spheroids $[9,11,12]$ which is no larger than $5 \mathrm{~mm}$ in diameter or length $[6,13,14]$ and are classified as primary and secondary microplastics. The former includes particles intentionally manufactured such as those found in beauty products, soaps, washing powders and clothing for example glitters. Secondary microplastics are particles obtained from the degradation or fragmentation of larger pieces of plastics [7,15,17]. The breakdown processes may involve microbial biodegradation, photo oxidative degradation and hydrolysis of plastics materials over a period of time $[6,14,18]$. Nano plastics are defined by their nanoscale dimension, with a size range of 1 to $100 \mathrm{~nm}$ (EFSA Panel on Contaminants in the Food Chain (CONTAM) 2016; [3,18,19].

Microplastics are very ubiquitous and their presence and accumulation in the environment threatens the ecological equilibrium, aquatic environment, human health, food sustainability and security $[6,7,20]$. The environmental and metabolic threats to marine organisms are attributable to the stable chemical and physical properties of the parent plastics, 
[21]. The plastics can absorb and adsorb toxic inorganic and organic compounds which can leach into the tissues of the marine organisms. Polychlorinated biphenyls (PCB's) and polycyclic aromatic hydrocarbons (PAH's) compounds are reportedly the most plastic/microplastic adsorbent $[6,10,13,19,22]$. The release rate of these chemical compounds is favoured by the $\mathrm{pH}$ of the medium, temperature, heat, UV light, mechanical and chemical abrasion [23]. The manufacturing additives such as bisphenol A, phthalates, nonylphenol, urethane foam and brominated flame retardant, used in production of plastics can become toxic residues [22,25].

The plastic fragments can accumulate in the gastrointestinal tract of marine organisms through ingestion and evidence of deep tissue penetration by particles of nano plastics as well as accumulation has been shown [19]. Earlier, Earlier in 2015, Koelmans et al. [3] showed that nano plastics such as those from polystyrene could cross the blood and brain barriers and Kashiwada (2006) reported the presence of nanoparticles in fish embryos and adults. Polystyrene is the moststudied and reported plastic pollutant in the marine environment [22] and polyvinyl chloride (PVC) and polyethylene terephthalate (PET) most identified microplastics particles. Galloway [23] also found studies that demonstrated the ability of particles in diameter less than $50 \mathrm{~nm}$ to pass into the bloodstream, the liver, then via the bile and the small intestine and end up being excreted with the faeces. Similarly, Koelmans, et al. [3] reviewed studies that reported evidence of nanoparticles uptake by the chorion of medaka (Oryzias latipes) eggs, passing into the yolk and the gallbladder during their embryonic growth and an accumulation in the intestine, gill, brain, liver, testis and the blood of the adults species. Studies have indicated that human exposure to microplastics and nano plastics is mostly through the diet $[3,6,8,26,27]$. Other human exposure routes are dust, soils, plants, textiles, industry and general waste $[28,29]$.

\section{The Hypotheses}

Following the literature review and supporting the aims, several hypotheses were proposed:

a) H1: there is a low consumer perception of the environmental and food safety threats of micro-nanoplastics.

b) H2: there is no significant difference in the consumer awareness of microplastics and nanoplastics.

c) H3: the consumers' awareness of the adverse effects of microplastics and nanoplastics is not linked to their education and the social group.

d) H4: awareness would heighten the consumers desire to support plastic reduction strategies.

\section{Methodology}

\section{Overview}

The study is twofold; a small group online survey supported by a critical literature review of relevant literature, published in recent years up to March 2020. The emphasis was on the presence of microplastics and nano plastics in the food chain. The survey was carried out using JISC online (formerly Bristol Online) and the questionnaire was designed to assess the consumer perception of the safety threats of microplastics and nano plastics and attitude towards the reduction of the use of plastics. This research project complied with the university's ethical guidelines.

\section{The Literature Search Strategy}

The selection of research and review articles was limited to papers published in English and more likely where an abstract was available. The literature search started in the beginning of March 2020 on science direct, EBSCOhost the university library search access, the library e-book collection, and google scholar. The references were stored in the RefWorks citing software authorised by the university. It was also used to search for research papers that came across while looking at other articles. RefWorks allows the acknowledgment of people's work directly on the document as well as the management of those references into a project folder. The keywords used for the journal articles search were the following words on their own or a combination of them: microplastics, nano plastics, food safety, marine environment, environmental pollution, and sustainability and consumer awareness. For the last keyword used, consumer awareness it was considered relevant to conduct a consumer survey to assess the people's understanding about the topical issue of microplastics and nano plastics in the environment and the potential risk it could cause to food safety and to human health.

\section{The Survey and Questionnaire}

The survey was anonymous, and the data was stored in the university database to comply with data protection GDPR (The General Data Protection Regulation 2016/679 requirements). The distribution of the survey was done using its link which was sent via LinkedIn, WhatsApp, email, and Facebook with specificity of only UK BAME (Black, Asian and Minority Ethnic) residents to participate. The participants gave their consent by completing the survey questionnaire with a covering letter which explained the time it would take to complete it, the aim of the survey, the right to withdraw and how the data will be stored and for how long. It also advised about the probable use of quotation from open questions answered. The questionnaire had different parts which were as follows: 
a) Part 1: the origin and awareness of microplastics and nanoplastics.

b) Part 2: awareness of the environmental and food safety implications of microplastics and nanoplastics.

c) Part 3: knowledge of schemes and policies for reduction of plastics.

d) Part 4: the participant's demographics.

\section{Critical Evaluation of Literature}

\section{Micro and Nano Plastics in the Environment}

Microplastics and nano plastics are ubiquitous in the environment, they can be found in every corner of the world, from the Artic to China, the United States via the Persian Gulf to Europe, Australia and Africa. The plastics debris in the environment as per the study by Geyer, et al. [30] gave an account of about 8300 million metric tons of new plastics produced in 2015, about 6300 million metric tons have been wasted, $79 \%$ has ended in landfills, $9 \%$ recycled and $12 \%$ incinerated. It has been estimated that by 2050, approximately 12000 million metric tons of plastics will be accumulated in landfills. The estimate in the ocean is about 1 million tons of plastic debris per square mile [1] with 7000 to 35000 tons floating in the open oceans and basins [14]. Furthermore Galloway [3] predicted that by 2050 there will be 33 billion tons more plastics particles on the planet and Farady [5] speculated that the plastics debris by weight will be greater than fish in the aquatic environment. These figures parallel the estimates for microplastics and nano plastics in the environment as the plastics degenerates into smaller fragments instead of demineralising [5,20]. The degradation could take centuries, (Farady 2019) [5] stated that $1 \mathrm{~mm}$ of microplastics could take up to 3 centuries to become nano plastics in a normal marine environment.

In the Netherlands sewage wastewater, Van Wezel et al. projected the concentration of primary microplastics released from cosmetics and other cleaning, washing and personal care products to be between 0.2 micro grams/ L to 66 micro grams/L at sewage treatment plant. Oni, et al. [31] showed that the predominant microplastics in a lake in Nigeria (Africa) were polyethylene terephthalate (PET) and polyvinyl chloride (PVC) which respectively account for $72.63 \%$ and $10.9 \%$ of particles during the dry season. The concentrations in the rainy season were $81.5 \%$ plasticised PVC and $4.2 \%$ for low density polyethylene (LDPE).

\section{Micro and Nano plastics in Food}

Several studies have shown the presence of micro- and nano- sized plastic particles in the food chain, for example, Van Cauwenberghe and Janssen [26]'s study on microplastics in bivalves cultured for human consumption, Galloway [3]'s book chapter on micro- and nano plastics and human health; Santillo, et al. [12] microplastics as contaminants in seafood; Li, et al. [28]'s on microplastics in mussels from UK coastal waters and supermarkets. Others $[13,14,20,32,33]$ investigated microplastics in seafood destined for human consumption and found that the contamination level of seafood sampled from the northern area of the Persian Gulf is about 0.2 to 21 particles per gram (wet weight). Li et al. [28] found a higher amount of microplastics in cooked mussels, about 1.4 particles per gram and 0.9 particles per gram in live mussels, thus suggesting a potential contamination during the processing of the product. Kutralam-Muniasamy et al. [34] analysed 23 samples of milk from different brands for sale and found $3 \pm 2$ to $11 \pm 3.54$ particles per litre with an overall average of $6.5 \pm 2.3$ particles per litre. Similarly, in China, Tong et al. [35] found $440 \pm 225$ particles, mainly polypropylene and polyethylene in tap water.

Investigation by Al-Sid-Cheikh et al. [36] showed a whole-body uptake of nano plastics especially those in size range of $24 \mathrm{~nm}$ by Pecten maximus, a commercial popular mollusc and Sökmen et al. [32] found that polystyrene nano plastics $(20 \mathrm{~nm})$ can bioaccumulate and cause damages to the DNA in the brain tissue of the embryo of zebrafish (Danio rerio). These demonstrated the ability of nano plastics to migrate across cellular membranes. Nano plastics can penetrate deep tissues and edible parts of fish, cause reproduction and growth defects, metabolic disorder and even death $[4,7,25]$. The study of the pacific mole crab (Emerita analoga) by Horn et al. [33] showed that microfibre contamination affects its fecundity and is manifested as a reduction in egg retention and a differential rate of embryonic development. There is also an increase in mortality amongst the pacific mole crab population exposed to microplastics compared to their control group.

\section{Consumer Awareness of Micro and Nano Plastics}

Very few studies have assessed the consumer understanding of the environmental and food safety issues concerning microplastics and nano plastics. Some of the studies assessed the consumer understanding based on use of body care products [15,29,37,38], plastic packaging and their end of life management [39,40], consumption of seafood [41] and other studies assessed the perceptions of plastic waste management [42] and the effectiveness of abatement campaigns [43]. Chang [37] assessed the awareness of microplastics in facial exfoliating products used regularly by students and found that the students have no knowledge about the content of their facial products and didn't realise that so many microplastic particles $(5000 \mathrm{~g}$ of microplastic - the equivalent of 2500 Ziploc sandwich bags $(16.5 \mathrm{~cm} \times 14.9 \mathrm{~cm})$ were washed off every year through the use of their favourite products.

Anderson et al. [15] carried out a study on the knowledge of microplastics in microbeads in personal care products using 3 focus groups: students, environmentalists and beauticians all with a mean age of 22 and mostly women. The participants 
were shocked and concerned especially when they found that the microbeads were made of plastics and are not of natural ingredients, do not disintegrate once washed off and end up in oceans via waste waters. The participants felt that the microbeads were not necessary and natural. The concern led them to suggest the following: clear labelling to enable an informed choice and more stringent measures from the government on manufacturers, for example, imposing a ban on the use of microbeads in cosmetics. Policy like this exists, in the US where the Microbeads Free Waters Act voted in 2015 stopped the manufacture of rinse off microbeads from July 2017 [44]. Anderson et al. [15] concluded that people have a greater sense of awareness when they can visualise the issue. They do stress the fact that education and raising awareness is not enough and that legislations are needed especially when the figures say that in the UK per year, about 680 tons of microbeads are used and in Europe 4130 tons with Switzerland and Norway included.

Peberdy, et al. [38] assessed the people's awareness of the impact of disposable menstrual sanitary products on the environment and found that the participants in majority were not aware of the plastic content of the products and hence the adverse environmental impact. They concluded that raising the awareness of the issue could positively shift purchasing habit of the consumers. The consumers were willing to forfeit the convenience and affordability of disposable pads. Henderson and Green [29] instead tried to assess the consumer understanding of plastics pollution, with a focus on microplastics. They 've used different focus groups made of people of different works of life with different interests and activities and level of education. Their results showed that websites and television are the major information source for microplastics. In general, the focus groups have no knowledge about microplastics pollution but have heard of it in the news.

\section{Control}

There is not a legislation per se that regulates micro- and nano plastics or considers micro and nano plastics as contaminants in foodstuff. However, there are few initiatives in responding to the issue from the European Union (EU), Africa, the World Health Organisation (WHO), the United States (US) and the United Kingdom (UK) in particular. Almost all the initiatives are for the reduction of plastic litter in the environment, the concern for the risk posed to human health is increasing as the evidence of their presence in seafood and effects on the metabolic functions of marine organisms emerge.

In the United States (US), the manufacture of cosmetic products that rinse off plastics microbeads was banned from the 1st of July 2017 [44]. In 2018, the United Kingdom (UK) followed, by imposing a similar ban on manufacture of microbeads [45]. The ban even though welcomed by campaigners is deficient as the use of microplastic particles in lipsticks, sun creams and paints are exempted. Furthermore in 2019, the Food Standards Agency (FSA)
UK, was tasked with a two-year research to assess the microbiological risk that contaminated microplastics could pose to human health [46]. Several plastic-reduction initiatives were introduced in the UK, amongst them the introduction in October 2015 of a charge, 5 pence on single use carrier bag. Again the achievement of objective of the initiative was partial as there are some exemptions, retailers with less than 250 employees were excluded and the money raised did not go to the government's treasury instead the UK companies were encouraged to make charitable use of the profits [47]. In 2018 , the charge was raised to 10 pence with effect from January 2020 , as the current consumption of single use carrier bags was estimated to be around 4.5 billion which the government aimed to reduce by the third year of the policy to 521 million. There are no published stats yet to ascertain whether it has been met [48]. Northern Ireland which introduced a 5p levy since 2013 was able to get the plastic bag usage down from 300 million to just under 100 million in $2017 / 2018$. This is a $2 / 3$ reduction in about 5 years. They have also managed to raise about 2.2 million pounds for their environmental fund [49].

The United Kingdom government was thinking of introducing a 25 pence "latte levy" on disposable cups hoping that consumers will change their habits and use more reusable cups [42]. There are about 7 million coffee cups that are used daily in the United Kingdom of which only 1 in 400 is recycled which equates to a recycling rate of $0.25 \%$. The cup producers failed according to Maye, et al. [50] to take responsibilities. The UK cost of recycling is down to $90 \%$ from taxpayer's money and $10 \%$ from businesses whereas in Germany it is $100 \%$ down from the producers. In France, the authorities instead are imposing more charges on businesses for putting more non-recyclable materials into the system. In the UK, the 'packaging producer responsibility scheme' is not working as it should according to the December 2017 audit report of the UK government, thus the publication in July 2019 of a 'plastic packaging tax' which will charge $£ 200$ per tons of plastic packaging that does not meet the requirement for $30 \%$ content of recycled plastic [39]. There will also be an introduction of a 'Deposit Return Scheme (DRS) '15 pence per container and funded by the packaging tax revenue [51]. A legislation on single use plastics such as straws, plastic cotton buds stem and plastics stirrers, is awaiting approval as a statutory instrument [52]. There is also a new environmental bill on a charge for single use plastic items. At European level, a proposal directive (EU) 2019/904 has been agreed and published by the member states which sets out the restriction on intentional use of microplastics by 2030 as well as the reduction of single use plastics. They also aim to make all plastic packaging in the EU market recyclable [39] by 2030. Portugal, like the United Kingdom introduced a tax on plastic bags in 2015 to implement the European directive 94/62/ EC which was amended by the directive 2018 / 852 on packaging waste. It resulted in a $74 \%$ reduction in the use of plastic carrier bags and an increase in the use of reusable ones 
(68\%) [53]. The charge on plastic bags and single use plastics policy is implemented to some extent worldwide and appears to be a key driver for the reduction of the use of plastics.

In Africa, many countries have policies to reduce the use and the sale of single use plastic bags, but enforcement is slack [54]. In 2011, Australia introduced a ban on single use plastics and a reduction in the use of conventional polyethylene bags by about 2600 tonnes by 2018. This reduction over seven years was not significant and the issue was compounded by an increase in the use of other types of plastics. However, the support for scheme by the communities rose significantly from $58 \%$ at the beginning of the ban in 2011 to $68 \%$ in 2018 [55]. Non statutory controls are widely available to raise public awareness and encourage the recycling of plastic materials as well as the use of alternatives. In the UK, there are sound local authority strategies to tackle plastic waste and encourage recycling, households are provided with specific recycling bins and bags, increasing the collection and the type of recyclable items, raising awareness by improving communication or investing in waste abatement campaigns [43].

a) The Waste and Resources Action Program (WRAP) is a registered UK charity which works with communities, businesses and governments to help them find practical solutions to improve resources efficiency, in collaboration with the UK governments and other stakeholders, designed the UK Plastics Pact which aim to achieve 4 key targets by 2025 :

b) $100 \%$ plastic packaging to be reusable, recyclable, or compostable,

c) $70 \%$ of plastic packaging effectively recycled or composted

d) take actions to eliminate the problem of single-use plastic packaging through redesign, innovation or alternative (reuse).

e) achieve a $30 \%$ average recycled content across all plastic packaging.

The UK government 25-year plan aims to eliminate all avoidable plastic by the year 2042 [42,51]. There are so many schemes that manufacturers and food retailers are using to reduce plastic waste and promote the use of more sustainable materials. For examples, Tesco with its Reuse and Repeat bags, Iceland which has introduced a paper shopping bag and Coop with a biodegradable compostable bag. There is a surging trend of shops where people can purchase groceries by bringing their own containers. Such initiatives can be seen on websites such as Werth London [56] which help people interested in more eco-friendly shopping experience, locate the "Best Zero Waste Shops" around London and the UK. Local authorities also contribute by implementing schemes at local level to help reduce plastic waste and encourage recycling from households and businesses around their boroughs.

\section{Results and Discussion}

\section{Overview}

The research was two pronged, a critical review supported by a small group survey. The former focusing on the presence of micronano plastic in the environment and food plus control systems, consumers and stake holder's awareness and behaviour studies. $69.4 \%$ of the participants ( $n=72$ ) were of black ethnicity (Figure 1 ). The hypotheses (H1 to H4) raised were supported to some extent, H1 was partially proven, there was a general awareness of the environmental threat of plastics, microplastics and nano plastics but no clear conclusion on the food safety threat. H2 was unproven as the awareness was quite greater for microplastics (77.8\%) than nano plastics (56.9\%). It can be concluded that majority of the participants were aware of these plastic fragments. Unsurprisingly, H3 was not supported, the level of awareness, at a glance, correlates positively with the participants' education and social group (Figure 2), $87.5 \%$ of the participants had higher education and $30.6 \%$ had an income above $£ 40,000$, well above the UK national average income of $£ 29,600$, Office for National Statistics's [57]. The result is expected as the more educated participants are likely to be higher earners and consequently better resourced to access an online survey. A wider poll involving non-online survey may provide a conclusive result. Finally, H4 was proven, the consumers were strongly in favour of the reduction strategies thus agreed with Chang [37] and Willis, et al. [43] who showed that awareness is crucial for a positive change in behaviour.

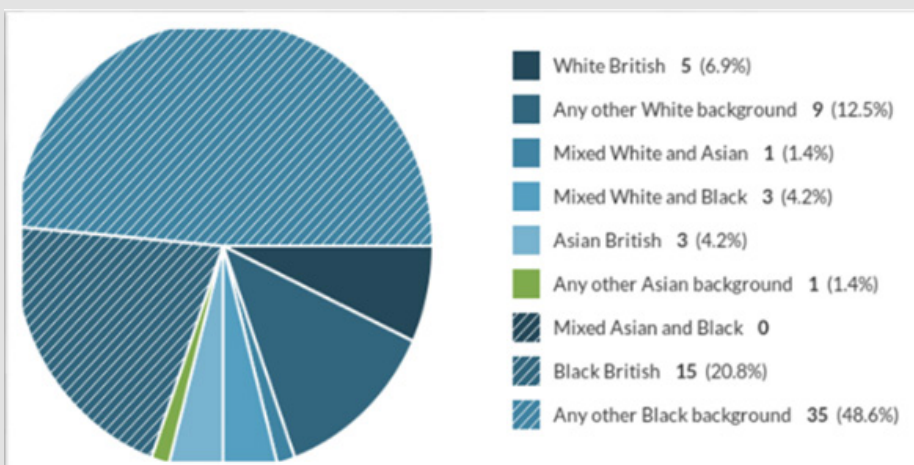

Figure 1: The ethnicity of the participants. 


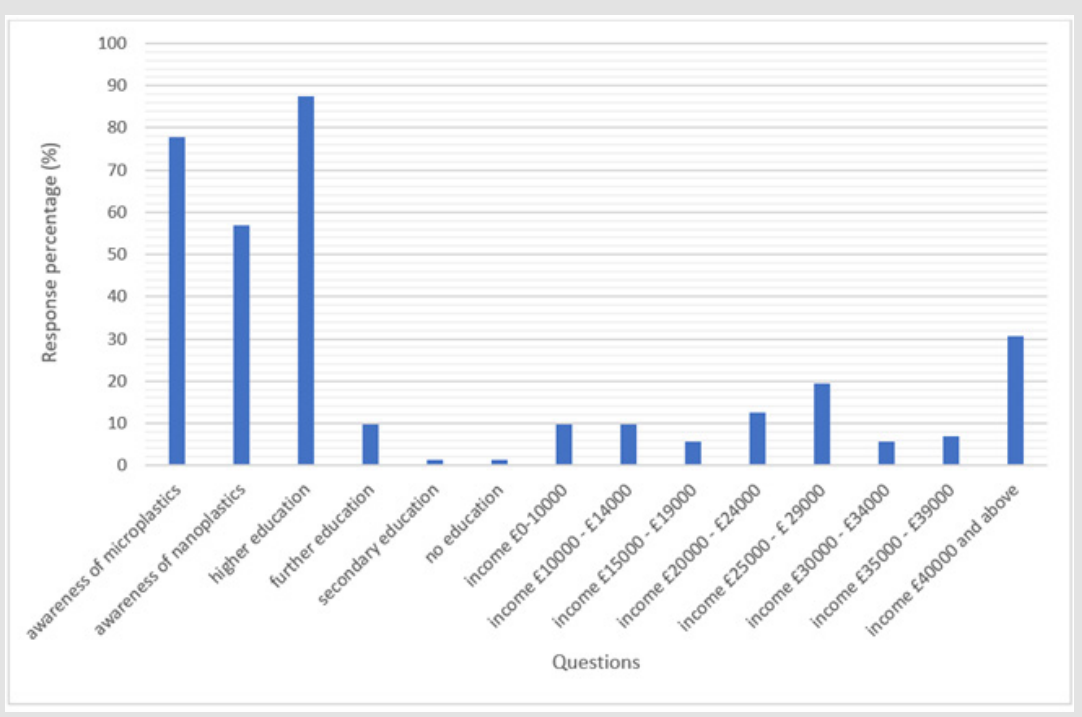

Figure 2: Comparison of the level of awareness of microplastics and nanoplastics with the participants' education and income.

\section{Literature Findings}

Analysis of the publications showed that there is an increasing awareness and that microplastics are widely found in aquatic organisms, thus consumption of these is a direct route to ingestion by human. Furthermore, the review showed that the awareness campaigns play a significant role, for example, Willis, et al. [43] found evidence of successful waste abatement campaign in Australia which has quite similar system as the UK. Thus, the campaign in the UK should be reinforced and relentless and more so as the awareness led to a shift towards plastic reduction strategies. Furthermore, Willis, et al. [43] also showed that investments in awareness campaigns rather than policies work best at reducing plastic litter. The key findings and conclusions are summarised (Tables 1 and 2).

Table 1: Research papers on presence of microplastics and/or nanoplastics in the environment and food.

\begin{tabular}{|c|c|c|c|c|c|}
\hline Year & Authors & Paper title & Aim and objectives & Conclusion & Comment \\
\hline 2014 & $\begin{array}{c}\text { Van } \\
\text { Cauwenberghe } \\
\text { and Janssen }\end{array}$ & $\begin{array}{l}\text { Microplastics in bivalves } \\
\text { cultured for human } \\
\text { consumption }\end{array}$ & $\begin{array}{l}\text { Investigation of the } \\
\text { presence of microplastics } \\
\text { in two species of } \\
\text { commercially grown } \\
\text { bivalves: Mytilus edulis and } \\
\text { Crassostrea giga. }\end{array}$ & $\begin{array}{l}\text { Microplastics were recovered } \\
\text { from the soft tissues of both } \\
\text { species. At time of human } \\
\text { consumption, } M \text {. edulis contained } \\
\text { on average } 0.36 \pm 0.07 \text { particles } \\
\text { g-1 (wet weight), and } 0.47 \pm 0.16 \\
\text { particles g- } 1 \text { ww was detected in } \\
\text { C. gigas. }\end{array}$ & $\begin{array}{l}\text { The detection allowed the } \\
\text { estimation of dietary exposure } \\
\text { of European consumers to } \\
\text { be up to } 11,000 \text { microplastic } \\
\text { fragments/year but estimating } \\
\text { the potential risks for human } \\
\text { health is not yet possible. }\end{array}$ \\
\hline 2015 & Li, et al. & $\begin{array}{l}\text { Microplastics in } \\
\text { commercial bivalves } \\
\text { from China }\end{array}$ & $\begin{array}{l}\text { Determine if the } \\
\text { commercial bivalves in } \\
\text { China have been polluted } \\
\text { by microplastics and to } \\
\text { distinguish the differences } \\
\text { of microplastic pollution } \\
\text { among the various genera. }\end{array}$ & $\begin{array}{c}2.1-10.5 \text { items/g. Fibres were } \\
\text { the most common microplastics. } \\
\text { Size }<250 \mu \mathrm{m} .33-84 \% \text { of the } \\
\text { total microplastics calculated by } \\
\text { species. }\end{array}$ & $\begin{array}{l}\text { The habitat of commercial } \\
\text { bivalves was polluted with } \\
\text { microplastics. }\end{array}$ \\
\hline 2018 & Naji, et al. & $\begin{array}{l}\text { Microplastics } \\
\text { contamination in } \\
\text { molluscs from the } \\
\text { northern part of the } \\
\text { Persian Gulf. }\end{array}$ & $\begin{array}{l}\text { To evaluate the occurrence } \\
\text { of microplastics in marine } \\
\text { life and seafood for human } \\
\text { consumption in the Persian } \\
\text { Gulf. }\end{array}$ & $\begin{array}{l}\text { The mean microplastics in all } \\
\text { species ranged from } 0.2 \text { to } 21.0 \\
\text { particles per g of soft tissue (wet } \\
\text { weight) and from } 3.7 \text { to } 17.7 \\
\text { particles per individual. } \\
\text { Microfibres are the most common } \\
\text { type and } 37-58 \% \text { of microplastics } \\
\text { fell into this size range } 10-25 \mu \mathrm{m} \\
\text { and most were polyethylene (PE), } \\
\text { polyethylene terephthalate (PET), } \\
\text { and nylon (PA). }\end{array}$ & $\begin{array}{l}\text { Molluscan shellfish from } \\
\text { the Persian Gulf contain } \\
\text { microplastics. } \\
\text { High concentration of } \\
\text { microplastics were found in } \\
\text { predatory species suggesting } \\
\text { trophic transfer of microplastics } \\
\text { in food web. }\end{array}$ \\
\hline
\end{tabular}




\begin{tabular}{|c|c|c|c|c|c|}
\hline 2018 & Li, et al. & $\begin{array}{l}\text { Microplastics in } \\
\text { mussels sampled from } \\
\text { coastal waters and } \\
\text { supermarkets in the } \\
\text { United Kingdom. }\end{array}$ & $\begin{array}{l}\text { The presence of } \\
\text { microplastics and other } \\
\text { anthropogenic debris in } \\
\text { seawater and mussels } \\
\text { (Mytilus edulis) from } \\
\text { coastal waters of the U.K., } \\
\text { as well as supermarket } \\
\text { sources. }\end{array}$ & $\begin{array}{c}\text { Microplasics detected in all } \\
\text { samples } \\
\text { Seawater samples: } 3.5 \pm 2.0 \\
\text { debris items/L on average (range: } \\
\text { 1.5-6.7 items/L) } \\
\text { Wild musse } 0.7 \text { to } 2.9 \text { items/g of } \\
\text { tissue and from } 1.1 \text { to } 6.4 \text { items/ } \\
\text { individuals } \\
\text { Supermarkets mussels pre- } \\
\text { cooked: } 1.4 \text { items/g } \\
\text { Live: } 0.9 \text { items/g } \\
43 \% \text { / } 57 \% \text { of debris items from } \\
\text { coastal / supermarket mussels } \\
\text { were microplastics. }\end{array}$ & $\begin{array}{l}\text { Predicted ingestion of } 70 \\
\text { microplastic items in } 100 \mathrm{~g} \\
\text { processed mussels by } \\
\text { consumers. } \\
\text { Supermarket mussels were } \\
\text { route for human exposure } \\
\text { and suggests that their } \\
\text { quantification be included } \\
\text { as food safety management } \\
\text { measures as well as for } \\
\text { environmental monitoring } \\
\text { health measures. }\end{array}$ \\
\hline 2018 & $\mathrm{Gu}$, et al. & $\begin{array}{l}\text { Bioaccessibility } \\
\text { and human health } \\
\text { implications of heavy } \\
\text { metals in different } \\
\text { trophic level marine } \\
\text { organisms: A case study } \\
\text { of the South China Sea. }\end{array}$ & $\begin{array}{l}\text { The total concentrations } \\
\text { and bioaccessibility of } \\
\text { heavy metals in edible } \\
\text { tissues and trophic levels } \\
\text { of } 12 \text { marine organism } \\
\text { species in the South China } \\
\text { Sea. }\end{array}$ & $\begin{array}{l}\text { Nickel (Ni) was present at the } \\
\text { highest concentration followed } \\
\text { in descending order by iron } \\
(\mathrm{Fe}) \text {, zinc }(\mathrm{Zn}), \text { manganese }(\mathrm{Mn}) \text {, } \\
\text { chromium }(\mathrm{Cr}) \text {, copper }(\mathrm{Cu}), \\
\text { cadmium (Cd) and lead }(\mathrm{Pb}) \\
\text { Cd had the highest percentage bio } \\
\text { accessibility }(61.91 \%) .\end{array}$ & $\begin{array}{c}\text { There is no biomagnification } \\
\text { among these trace metals. This } \\
\text { possess another route for heavy } \\
\text { metal contamination }\end{array}$ \\
\hline 2018 & Chae, et al. & $\begin{array}{l}\text { Trophic transfer and } \\
\text { individual impact of } \\
\text { nano-sized polystyrene } \\
\text { in a four-species } \\
\text { freshwater food chain. }\end{array}$ & $\begin{array}{l}\text { Investigation of the trophic } \\
\text { transfer, individual impact, } \\
\text { and embryonic uptake of } \\
\text { fluorescent nano-sized } \\
\text { polystyrene plastics } \\
\text { (nanoplastics) through } \\
\text { direct exposure in a } \\
\text { freshwater ecosystem, with } \\
\text { a food chain containing } \\
\text { four species. }\end{array}$ & $\begin{array}{l}\text { Nanoplastics (NPs) adhered } \\
\text { to the surface of the primary } \\
\text { producer and were present } \\
\text { in the digestive organs of the } \\
\text { higher trophic level species. They } \\
\text { adversely affected fish activity } \\
\text { and induced histopathological } \\
\text { changes in the livers of fish } \\
\text { that were directly exposed. } \\
\text { Nanoplastics penetrated the } \\
\text { embryo walls and were present in } \\
\text { the yolk sac of hatched juveniles. }\end{array}$ & $\begin{array}{l}\text { Nanoplastics are easily } \\
\text { transferred through the food } \\
\text { chain, maybe due to high } \\
\text { experimental dosages. The } \\
\text { results strongly point to the } \\
\text { potential health risks of NPs } \\
\text { exposure. }\end{array}$ \\
\hline 2018 & $\begin{array}{l}\text { Al-Sid-Cheikh, } \\
\text { et al. }\end{array}$ & $\begin{array}{l}\text { Uptake, whole- } \\
\text { body distribution, } \\
\text { and depuration of } \\
\text { nanoplastics by the } \\
\text { scallop Pecten maximus } \\
\text { at environmentally } \\
\text { realistic concentrations. }\end{array}$ & $\begin{array}{c}\text { Tracking plastic } \\
\text { particles in organisms at } \\
\text { environmentally relevant } \\
\text { concentrations and } \\
\text { highlights the need for new } \\
\text { approaches }\end{array}$ & $\begin{array}{l}\text { Rapid and greater uptake } \\
\text { for } 24 \mathrm{~nm} \text { than for } 250 \mathrm{~nm} \\
\text { particles.250nm NPs in the } \\
\text { intestine, while } 24 \mathrm{~nm} \text { particles } \\
\text { were dispersed throughout } \\
\text { the whole-body. After } 14 \text { days } \\
\text { (d) } 24 \mathrm{~nm} \text { particles not detectable } \\
\text { but } 250 \mathrm{~nm} \text { lasted } 48 \mathrm{~d}\end{array}$ & $\begin{array}{l}\text { Particle size apparently } \\
\text { influenced the biokinetics and } \\
\text { suggests a need for chronic } \\
\text { exposure studies.Nanoparticle } \\
\text { composition may also somehow } \\
\text { influence the uptake tissue } \\
\text { distributions. }\end{array}$ \\
\hline 2019 & Giani, et al. & $\begin{array}{l}\text { Microplastics occurrence } \\
\text { in edible fish species } \\
\text { (Mullus barbatus and } \\
\text { Merluccius merluccius) } \\
\text { collected in three } \\
\text { different geographical } \\
\text { sub-areas of the } \\
\text { Mediterranean Sea. }\end{array}$ & $\begin{array}{c}\text { Occurrence of } \\
\text { microplastics in } 229 \\
\text { demersal fish from the } \\
\text { species of Mullus barbatus } \\
\text { and Merluccius in } 3 \\
\text { different location of the } \\
\text { Mediterranean Sea. }\end{array}$ & $\begin{array}{l}\text { Plastic fragments (ranging from } \\
0.10 \text { to } 6.6 \mathrm{~mm} \text { ) were detected in } \\
23.3 \% \text { of the total investigated } \\
\text { fish; a total of } 65 \text { plastic particles } \\
\text { (66\% constituted by fibres) were } \\
\text { recorded. }\end{array}$ & $\begin{array}{c}\text { The percentage of plastic } \\
\text { ingestion shows high variability } \\
\text { between the two species and } \\
\text { among the different sampling } \\
\text { areas. }\end{array}$ \\
\hline 2019 & $\begin{array}{c}\text { Akhbarizadeh, } \\
\text { et al. }\end{array}$ & $\begin{array}{c}\text { Investigating } \\
\text { microplastics } \\
\text { bioaccumulation and } \\
\text { biomagnification in } \\
\text { seafood from the Persian } \\
\text { Gulf: a threat to human } \\
\text { health? }\end{array}$ & $\begin{array}{c}\text { Investigation of } \\
\text { bioaccumulation, } \\
\text { biomagnification, and } \\
\text { potential human intake of } \\
\text { microplastics in muscles } \\
\text { and gills of five popular } \\
\text { commercial species ( } 3 \text { fish, } \\
1 \text { crab, and } 1 \text { prawn) from } \\
\text { the Persian Gulf. }\end{array}$ & $\begin{array}{l}\text { The highest mean } 0.360 \text { items/g } \\
\text { of muscle and lowest } 0.158 \\
\text { items/g The results of the trophic } \\
\text { magnification factor (TMF) } \\
\text { and biomagnification factor } \\
\text { (BMF) calculation indicated } \\
\text { that microplastics were not } \\
\text { biomagnified in edible parts }\end{array}$ & $\begin{array}{l}\text { Microplastics trophic } \\
\text { dilution occurs rather than } \\
\text { magnification in edible parts of } \\
\text { seafood. Routine consumption } \\
\text { of high doses of the studied } \\
\text { seafood should be controlled } \\
\text { for vulnerable groups such as } \\
\text { pregnant / lactating women and } \\
\text { their children to ensure their } \\
\text { safety. }\end{array}$ \\
\hline
\end{tabular}




\begin{tabular}{|c|c|c|c|c|c|}
\hline 2019 & Barboza, et al. & $\begin{array}{l}\text { Microplastics in wild fish } \\
\text { from North East Atlantic } \\
\text { Ocean and its potential } \\
\text { for causing neurotoxic } \\
\text { effects, lipid oxidative } \\
\text { damage, and human } \\
\text { health risks associated } \\
\text { with ingestion exposure. }\end{array}$ & $\begin{array}{l}\text { Investigated the } \\
\text { toxicological effects } \\
\text { derived from the ingestion } \\
\text { of microplastics in wild } \\
\text { conditions. Microplastics } \\
\text { contamination and } \\
\text { effect biomarkers were } \\
\text { investigated in three } \\
\text { commercially important } \\
\text { fish species from the North } \\
\text { East Atlantic Ocean. }\end{array}$ & $\begin{array}{c}150 \text { analysed fish (50 per } \\
\text { species), } 49 \% \text { had microplastics. } \\
32 \% \text { had microplastics in dorsal } \\
\text { muscle, with a total mean of } 0.054 \\
\pm 0.099 \text { microplasticsitems/g. } \\
\text { Microplasticswere found in the } \\
\text { GI tract, gills and dorsal muscle. } \\
\text { Fish with cc had significantly (p } \\
\leq 0.05 \text { ) higher lipid peroxidation } \\
\text { levels in the brain, gills and dorsal } \\
\text { muscle, and increased brain } \\
\text { acetylcholinesterase activity. }\end{array}$ & $\begin{array}{l}\text { Fish consumption is one of } \\
\text { the routes of human exposure } \\
\text { to microplastics therefore the } \\
\text { emphasis is for more research, } \\
\text { risk assessment and adoption } \\
\text { of measures to minimize human } \\
\text { exposure to these particles. }\end{array}$ \\
\hline 2020 & Horn, et al. & $\begin{array}{c}\text { Effects of } \\
\text { environmentally } \\
\text { relevant concentrations } \\
\text { of microplastic fibres } \\
\text { on Pacific mole crab } \\
\text { (Emerita analoga) } \\
\text { mortality and } \\
\text { reproduction. }\end{array}$ & $\begin{array}{l}\text { Examination of microfibers } \\
\text { on adult mortality, } \\
\text { reproductive output, and } \\
\text { embryonic development } \\
\text { of the filter feeding Pacific } \\
\text { mole crab (Emerita } \\
\text { analoga). }\end{array}$ & $\begin{array}{l}\text { Pacific mole crabs exposed } \\
\text { to polypropylene rope had } \\
\text { increased adult crab mortality, } \\
\text { and decreased retention of egg } \\
\text { clutches, causing variability in } \\
\text { embryonic development rates. }\end{array}$ & $\begin{array}{l}\text { Demonstrated that microplastic } \\
\text { ingestion by the pacific mole } \\
\text { crab influenced its mortality } \\
\text { and embryonic development. } \\
\text { There is still a gap in the current } \\
\text { knowledge on the impact of } \\
\text { microplastics. }\end{array}$ \\
\hline 2020 & $\begin{array}{l}\text { Kutralam- } \\
\text { Muniasamy, } \\
\text { et al. }\end{array}$ & $\begin{array}{l}\text { Branded milks - } \\
\text { Are they immune } \\
\text { from microplastics } \\
\text { contamination? }\end{array}$ & $\begin{array}{l}\text { Better assessment of } \\
\text { diversified consumer } \\
\text { products for microplastic } \\
\text { contamination thus the } \\
\text { aim to demonstrate the } \\
\text { presence of microplastics } \\
\text { on dairy milk products. }\end{array}$ & $\begin{array}{l}\text { Results confirmed the ubiquity of } \\
\text { microplastics in the analysed } 23 \\
\text { samples and showed variability } \\
\text { ranging between } 3 \pm 2 \text { to } 11 \pm \\
3.54 \text { particles / } \mathrm{L} \text { with an overall } \\
\text { average of } 6.5 \pm 2.3 \text { particles / } \\
\text { LMicroplastics particles exhibited } \\
\text { variety of colours (blue, brown, } \\
\text { red and pink), shapes (fibres and } \\
\text { fragments) and sizes ( } 0.1-5 \mathrm{~mm} \text { ). }\end{array}$ & $\begin{array}{l}\text { Thermoplastic sulfone } \\
\text { polymers (polyethersulfone } \\
\text { and polysulfone) were common } \\
\text { types of microplastics in milk } \\
\text { samples. The findings could } \\
\text { help develop a baseline outlook } \\
\text { for microplastics contamination } \\
\text { in dairy products and which } \\
\text { control and preventive } \\
\text { measures to take to avoid them. }\end{array}$ \\
\hline 2020 & Tong, et al. & $\begin{array}{l}\text { Occurrence and } \\
\text { identification of } \\
\text { microplastics in tap } \\
\text { water from China. }\end{array}$ & $\begin{array}{c}\text { Investigation of the } \\
\text { occurrence of microplastics } \\
\text { in tap water from different } \\
\text { cities in China. }\end{array}$ & $\begin{array}{l}\text { The amount of microplastics } \\
\text { in tap water varied from } 440 \\
\pm 275 \text { particles/ L . Particles } \\
\text { smaller than } 50 \mu \mathrm{m} \text { significantly } \\
\text { predominated in most of the tap } \\
\text { water samples. The majority of } \\
\text { the microplastics comprised of } \\
\text { polyethylene and polypropylene. }\end{array}$ & $\begin{array}{l}\text { Drinking water treatment } \\
\text { plants have to face the problem } \\
\text { of microplastic pollution in tap } \\
\text { water due to their potential eco- } \\
\text { toxicological effects on humans. }\end{array}$ \\
\hline 2020 & Oni, et al. & $\begin{array}{l}\text { Comparing microplastics } \\
\text { contaminants in (dry } \\
\text { and raining) seasons } \\
\text { for Ox- Bow Lake in } \\
\text { Yenagoa, Nigeria. }\end{array}$ & $\begin{array}{c}\text { Investigation of } \\
\text { the occurrence } \\
\text { and distribution } \\
\text { of microplastics } \\
\text { (microplastics) during dry } \\
\text { and raining seasons based } \\
\text { on } 10 \text { sections of OX- Bow } \\
\text { Lake Yenagoa, Nigeria } \\
\text { for surface water and } \\
\text { sediments. }\end{array}$ & $\begin{array}{l}\text { In dry season, PET and plasticised } \\
\text { PVC were the predominant } \\
\text { microplastics; they both account } \\
\text { for } 72.63 \% \text { and } 10.9 \% \text { of surface } \\
\text { water and sediment samples. } \\
\text { During the raining season } \\
\text { plasticised PVC accounted } \\
\text { for } 81.5 \% \text { and low-density } \\
\text { polyethylene } 4.2 \% \text {. }\end{array}$ & $\begin{array}{l}\text { There is a high presence of } \\
\text { microplastics in OX -Bow Lake. }\end{array}$ \\
\hline
\end{tabular}

Table 2: Consumers and stake holders' awareness of microplastics and plastic.

\begin{tabular}{|c|c|c|c|c|c|}
\hline Year & Authors & Paper title & Aims and Objectives & Conclusion & Comments \\
\hline 2015 & Chang M & $\begin{array}{l}\text { Reducing microplastics } \\
\text { from facial exfoliating } \\
\text { cleansers in wastewater } \\
\text { through treatment } \\
\text { versus consumer product } \\
\text { decisions. }\end{array}$ & $\begin{array}{l}\text { To characterize the microbeads } \\
\text { found in facial exfoliating } \\
\text { cleansers to better understand } \\
\text { how to reduce this source of } \\
\text { pollution through consumer } \\
\text { use and wastewater treatment } \\
\text { solutions. }\end{array}$ & $\begin{array}{c}\text { Most of the study population did } \\
\text { use a facial scrub, they were not } \\
\text { aware that many contained plastic } \\
\text { particles.5000 g of microplastic } \\
\text { - the equivalent of } 2500 \text { Ziploc } \\
\text { sandwich bags }(16.5 \mathrm{~cm} \times 14.9 \\
\mathrm{cm}) .\end{array}$ & $\begin{array}{l}\text { The awareness of an } \\
\text { issue has an impact on } \\
\text { future behaviour. }\end{array}$ \\
\hline 2016 & $\begin{array}{l}\text { Anderson, } \\
\text { et al. }\end{array}$ & $\begin{array}{l}\text { Microplastics in } \\
\text { personal care products: } \\
\text { Exploring perceptions } \\
\text { of environmentalists, } \\
\text { beauticians and students. }\end{array}$ & $\begin{array}{l}\text { To explore participants' } \\
\text { responses to the use of } \\
\text { microplastics in personal care } \\
\text { and cosmetic products. }\end{array}$ & $\begin{array}{l}\text { Visualisation is regarded as a } \\
\text { crucial process in communicating } \\
\text { environmental issues that are not } \\
\text { accessible to direct experience. } \\
\text { Use of microbeads in products } \\
\text { was judged unnatural and } \\
\text { unnecessary }\end{array}$ & $\begin{array}{l}\text { Becoming aware of the } \\
\text { issue has an impact on } \\
\text { opinion }\end{array}$ \\
\hline
\end{tabular}




\begin{tabular}{|c|c|c|c|c|c|}
\hline 2018 & Willis, et al. & $\begin{array}{l}\text { How successful are waste } \\
\text { abatement campaigns and } \\
\text { government policies at } \\
\text { reducing plastic waste into } \\
\text { the marine environment? }\end{array}$ & $\begin{array}{l}\text { To evaluate how effective } \\
\text { various strategies are at } \\
\text { reducing plastic waste } \\
\text { into the environment, the } \\
\text { analysis compared the level } \\
\text { of investment, and type of } \\
\text { waste abatement policies and } \\
\text { programs implemented by local } \\
\text { governments in Australia. }\end{array}$ & $\begin{array}{l}\text { Investments in campaigns led to } \\
\text { larger reductions of waste in the } \\
\text { environment than did investment } \\
\text { in policies. }\end{array}$ & $\begin{array}{l}\text { Awareness campaigns } \\
\text { play a significant part } \\
\text { in the reduction of } \\
\text { waste and should be } \\
\text { the focal point of any } \\
\text { waste management } \\
\text { strategies. }\end{array}$ \\
\hline 2018 & $\begin{array}{l}\text { Jacobs, } \\
\text { et al. }\end{array}$ & $\begin{array}{l}\text { Consumer response to } \\
\text { health and environmental } \\
\text { sustainability information } \\
\text { regarding seafood } \\
\text { consumption. }\end{array}$ & $\begin{array}{l}\text { Possible drivers for behavioural } \\
\text { change regarding seafood } \\
\text { consumption frequency and } \\
\text { sustainable seafood buying } \\
\text { frequency are studied following } \\
\text { exposure to the message. }\end{array}$ & $\begin{array}{l}\text { Attitude towards the message and } \\
\text { the option to optimise consumers' } \\
\text { choice of seafood species } \\
\text { favouring sustainability were } \\
\text { significant determinants of change } \\
\text { in the intention to buy sustainable } \\
\text { seafood. }\end{array}$ & $\begin{array}{l}\text { Consumer attitude } \\
\text { change as they } \\
\text { become aware of the } \\
\text { implications to their } \\
\text { health. }\end{array}$ \\
\hline 2018 & $\begin{array}{l}\text { Praveena, } \\
\text { et al. }\end{array}$ & $\begin{array}{l}\text { Exploration of } \\
\text { microplastics from } \\
\text { personal care and cosmetic } \\
\text { products and its estimated } \\
\text { emissions to marine } \\
\text { environment: An evidence } \\
\text { from Malaysia. }\end{array}$ & $\begin{array}{l}\text { Understand microplastics } \\
\text { from personal care and } \\
\text { cosmetic products in } \\
\text { Malaysia via quantification } \\
\text { and characterization of } \\
\text { microplastics together with } \\
\text { emission estimation to marine } \\
\text { environment. }\end{array}$ & $\begin{array}{l}\text { Top ten personal care and } \\
\text { cosmetic products usage } \\
\text { identified.Particles sizes: } \\
\text { Toothpaste: } 3-145 \mu \mathrm{m} \text { Facial } \\
\text { cleanser / scrub to } 10-178 \mu \mathrm{m} \\
\text { shows evidence of the presence of } \\
\text { microplastics. }\end{array}$ & $\begin{array}{l}\text { Personal care and } \\
\text { cosmetic products } \\
\text { are one of the sources } \\
\text { for microplastics in } \\
\text { Malaysia and } 0.199 \\
\text { trillion microplastics } \\
\text { estimated to be } \\
\text { released per year. }\end{array}$ \\
\hline 2019 & $\begin{array}{l}\text { Peberdy, } \\
\text { et al. }\end{array}$ & $\begin{array}{l}\text { A study into public } \\
\text { awareness of the } \\
\text { environmental Impact of } \\
\text { menstrual products and } \\
\text { product choice. }\end{array}$ & $\begin{array}{l}\text { To find out whether people that } \\
\text { are more aware of the damage } \\
\text { are likely to make choices } \\
\text { that are less harmful to the } \\
\text { environment. }\end{array}$ & $\begin{array}{l}\text { Found out that those with a } \\
\text { higher awareness are more likely } \\
\text { to choose products that are less } \\
\text { harmful to the environment. }\end{array}$ & $\begin{array}{l}\text { Awareness is } \\
\text { paramount and has } \\
\text { a definite impact on } \\
\text { people's choice of } \\
\text { product. }\end{array}$ \\
\hline 2019 & WRAP & $\begin{array}{c}\text { Citizens' attitudes \& } \\
\text { behaviours relating to } \\
\text { food waste, packaging and } \\
\text { plastic packaging }\end{array}$ & $\begin{array}{l}\text { Assess citizens' views in } \\
\text { relation to food waste and food } \\
\text { packaging and compare this to } \\
\text { the previous survey undertaken } \\
\text { in } 2012\end{array}$ & $\begin{array}{c}\text { Public concern has doubled from } \\
\text { the } 2012 \text { survey. Public support } \\
100 \% \text { recyclable packaging. High } \\
\text { public awareness of packaging in } \\
\text { preventing food waste. }\end{array}$ & $\begin{array}{l}\text { Public more conscious } \\
\text { about the problematic } \\
\text { of plastic packaging } \\
\text { and demand of more } \\
\text { sustainable packaging } \\
\text { and as well as more } \\
\text { effective waste } \\
\text { management }\end{array}$ \\
\hline 2019 & $\begin{array}{l}\text { McNicholas } \\
\text { and Cotton, }\end{array}$ & $\begin{array}{l}\text { Stakeholder perceptions } \\
\text { of marine plastic waste } \\
\text { management in the United } \\
\text { Kingdom. }\end{array}$ & $\begin{array}{l}\text { Understand the diverse array } \\
\text { of stakeholder perspectives } \\
\text { on ocean plastic pollution, } \\
\text { economic policy and } \\
\text { consumption responsibilities. }\end{array}$ & $\begin{array}{l}\text { A clear consensus that current and } \\
\text { proposed government policy is not } \\
\text { radical enough - the focus needs } \\
\text { to move beyond single-product } \\
\text { taxes and levies on disposal items } \\
\text { (e.g. bags, coffee cups), to a deeper } \\
\text { reflection about public awareness } \\
\text { raising and education, defining } \\
\text { waste responsibilities more } \\
\text { clearly, and working to change the } \\
\text { habits and unsustainable practices } \\
\text { of consumers in the face of public } \\
\text { apathy and a resistant retail } \\
\text { environment. }\end{array}$ & $\begin{array}{l}\text { Majority stakeholder } \\
\text { responses in this } \\
\text { study advocate radical } \\
\text { positive actions } \\
\text { to increase public } \\
\text { interest, habituative } \\
\text { personal pro- } \\
\text { environmental action, } \\
\text { encourage retailer } \\
\text { responsibility and } \\
\text { lobby for policy change. }\end{array}$ \\
\hline 2019 & $\begin{array}{l}\text { Dilkes- } \\
\text { Hoffman, } \\
\text { et al. }\end{array}$ & $\begin{array}{l}\text { Public attitudes towards } \\
\text { bioplastics - knowledge, } \\
\text { perception and end-of-life } \\
\text { management. }\end{array}$ & $\begin{array}{l}\text { To understand current } \\
\text { knowledge and perceptions } \\
\text { regarding bioplastics }\end{array}$ & $\begin{array}{l}\text { The Australian public's } \\
\text { knowledge of bioplastics is low, } \\
\text { but perception, particularly of } \\
\text { biodegradable plastics, is positive. } \\
\text { Biodegradable plastics were } \\
\text { perceived as better for the } \\
\text { environment than "normal } \\
\text { plastics" and even "easily } \\
\text { recyclable". }\end{array}$ & $\begin{array}{l}\text { People are ready for } \\
\text { alternatives but do } \\
\text { want government } \\
\text { and local authorities' } \\
\text { implementation for } \\
\text { clear labelling and } \\
\text { waste management. }\end{array}$ \\
\hline
\end{tabular}




\begin{tabular}{|c|c|c|c|c|c|}
\hline 2020 & $\begin{array}{l}\text { Henderson } \\
\text { and Green, }\end{array}$ & $\begin{array}{c}\text { Making sense of } \\
\text { microplastics? Public } \\
\text { understandings of plastic } \\
\text { pollution. }\end{array}$ & $\begin{array}{l}\text { This paper explores people's } \\
\text { knowledge and understandings } \\
\text { of microplastics; the role of } \\
\text { media in framing perceptions } \\
\text { and socio-cultural dimensions } \\
\text { to popular solutions to reduce } \\
\text { single-use plastics }\end{array}$ & $\begin{array}{l}\text { Public understandings of plastic } \\
\text { pollution and of the emerging } \\
\text { topic of microplastics are } \\
\text { intertwined with media messages } \\
\text { and existing social practices. } \\
\text { We are therefore unlikely to } \\
\text { develop effective solutions to } \\
\text { mitigating plastic waste without } \\
\text { first mapping how different social } \\
\text { groups engage with plastics in } \\
\text { everyday life. }\end{array}$ & $\begin{array}{c}\text { The media and social } \\
\text { media play a major role } \\
\text { on how the problematic } \\
\text { of microplastics is } \\
\text { understood by the } \\
\text { public. }\end{array}$ \\
\hline 2020 & Friedrich D. & $\begin{array}{l}\text { How regulatory measures } \\
\text { towards biobased } \\
\text { packaging influence the } \\
\text { strategic behaviour of the } \\
\text { retail industry: A micro } \\
\text { empirical study. }\end{array}$ & $\begin{array}{l}\text { A study to investigate the } \\
\text { product-related responses from } \\
\text { retailers ( } 253 \text { German industry } \\
\text { decision makers) to avoid } \\
\text { plastics. }\end{array}$ & $\begin{array}{l}\text { Additional costs of switching to } \\
\text { biomaterials are more likely to } \\
\text { be passed on to the market by } \\
\text { SMEs }(100 \%) \text { in the form of price } \\
\text { increases.Quality reductions } \\
\text { tend to be considered by the food } \\
\text { industry.Proposition to indicate } \\
\text { the packing's CO2-emissions using } \\
\text { a traffic light scheme. Trading } \\
\text { companies in general had only a } \\
\text { small influence on the packaging } \\
\text { properties of their suppliers' } \\
\text { products }(<32 \%) \text {. }\end{array}$ & $\begin{array}{l}\text { Impulses for plastic } \\
\text { avoidance should } \\
\text { rather be set by } \\
\text { government regulatory } \\
\text { instruments than by } \\
\text { self-regulation of the } \\
\text { retail industry. } \\
\text { An average of } 30 \% \\
\text { plastic recycling in } \\
\text { packaging, is already } \\
\text { making a significant } \\
\text { contribution to plastic } \\
\text { avoidance by the retail } \\
\text { industry. }\end{array}$ \\
\hline
\end{tabular}

The Small Group Survey: The Consumer Perception- A

\section{Global Approach}

Table 3 summarised the small group survey which as a whole has informed on the level of understanding by the participants of the origin of micro- and nano plastics, their presence in the food chain and the means by which they become aware of the issues. It also highlighted the attitude towards the reduction of plastics litter, the understanding of government and local authorities' schemes and initiatives. There was also a glimpse of the link between the level of awareness and education and earnings within the group (Figure 2). The results in all cases showed low standard deviation and a coefficient of variation less than one (CV >= 1). The survey like the literature suggested that awareness campaign is the main driver for consumer perception of the safety threat of plastics and the positive change in behaviour towards the use of plastics. The focus appears to be on plastics instead of their degradation products. Chang [37] showed that consumers were not aware that the exfoliating agents contain microplastics. These unlike plastics litters lack visibility. There is no clarity of the consumer's ability to distinguish plastics from microplastic or nano plastic although the consumers' awareness of micro-nano plastics lags the awareness for plastics. Over 30 questions were posed but the analysis focused on direct questions on awareness and understanding of the safety of microplastics and nano plastics in the environment and in food. There were $72(\mathrm{n}=72)$ respondents.

Table 3: A summary of the survey responses.

\begin{tabular}{|c|c|c|c|c|c|}
\hline \multicolumn{2}{|r|}{ Survey Questions } & \multicolumn{2}{|l|}{ Responses (\%) } & \multirow{2}{*}{$\begin{array}{c}\text { Mean Rank } \\
1.22\end{array}$} & \multirow{2}{*}{$\begin{array}{c}\text { Standard deviation } \\
0.42\end{array}$} \\
\hline 1 & Have you ever heard about microplastics? & 77.8 & 22,2 & & \\
\hline 2 & Have you ever heard about nanoplastics? & 56.9 & 43.1 & 1.43 & 0.25 \\
\hline 3 & $\begin{array}{l}\text { What is the main source where you have heard about } \\
\text { them? }\end{array}$ & $\begin{array}{l}\text { TV documentary (31.95\%) } \\
\text { News (25\%) } \\
\text { Environmental Campaign } \\
(6.9 \%) \\
\text { Local Authority }(0)\end{array}$ & & 3.38 & 2.24 \\
\hline 4 & $\begin{array}{l}\text { Do you know where microplastics and nanoplastics are } \\
\text { coming from? }\end{array}$ & 58.3 & 41.7 & 1.42 & 0.24 \\
\hline 5 & Where do you think they can be found? & $\begin{array}{c}\text { Ocean (55.6) } \\
\text { Beauty products (26.4) } \\
\text { Fish (4.2) } \\
\text { Seafood (2.8) }\end{array}$ & & 2.44 & 1.79 \\
\hline 6 & $\begin{array}{l}\text { Do you use products that contains microbeads such } \\
\text { as toothpaste, exfoliating gels, soaps, washing powder } \\
\text { etc...? }\end{array}$ & 86.1 & 13.9 & 1.14 & 0.351 \\
\hline
\end{tabular}




\begin{tabular}{|c|c|c|c|c|c|}
\hline 7 & Shopping frequency (weekly) & $\begin{array}{l}\text { Once (50) } \\
\text { Twice (37.5) } \\
\text { Thrice (9.7) }\end{array}$ & & 1.69 & 0.92 \\
\hline 8 & $\begin{array}{l}\text { On average how many single use plastic bag do you buy } \\
\text { when doing your shopping? }\end{array}$ & $\begin{array}{l}\text { None (58.3) } \\
\text { One (22.2) } \\
\text { More than one (19.4) }\end{array}$ & & 1.86 & 1.44 \\
\hline 9 & If you use your own bags, are they reusable ones? & 91.7 & 8.3 & 1.08 & 0.28 \\
\hline 10 & $\begin{array}{l}\text { Would you be happy to see plastic bags and packaging } \\
\text { completely removed from supermarkets? }\end{array}$ & 66.7 & 33.3 & 1.33 & 0.47 \\
\hline 11 & $\begin{array}{l}\text { Would you be happy to pay more for biodegradable bags } \\
\text { or for products that have biodegradable packaging. }\end{array}$ & 72.2 & 27.8 & 1.28 & 0.45 \\
\hline 12 & $\begin{array}{l}\text { Is your diet made mostly of seafood products such as } \\
\text { prawns, mussels, oysters, fish, crabs etc...? }\end{array}$ & 13.9 & 86.19 & 1.86 & 0.35 \\
\hline 13 & $\begin{array}{l}\text { Do you think that the food you consume can be } \\
\text { contaminated with microplastics }\end{array}$ & 87.5 & 12.5 & 1.13 & 0.33 \\
\hline 14 & $\begin{array}{l}\text { Do you think that microplastics and nanoplastics can be } \\
\text { toxic or can carry toxic materials? }\end{array}$ & 97.2 & 2.8 & 1.03 & 0.16 \\
\hline 15 & $\begin{array}{l}\text { Do you think that consuming microplastics could affect } \\
\text { your health in the long term? }\end{array}$ & 97.2 & 2.8 & 1.03 & 0.16 \\
\hline 16 & $\begin{array}{l}\text { Do you know the amount of plastics that is wasted in } \\
\text { your borough every year? }\end{array}$ & $\begin{array}{c}\text { Do not know } \\
(83.3)\end{array}$ & & 1.53 & 1.32 \\
\hline 17 & How do you think that microplastics could be reduced? & Varied & - & - & - \\
\hline 18 & Do you recycle your plastic waste? & 94.4 & 5.6 & 106 & 0.23 \\
\hline 19 & $\begin{array}{l}\text { Can you quantify in } \mathrm{Kg} \text { the amount of plastic you waste } \\
\text { in a month? }\end{array}$ & Less than $500 \mathrm{~g}$ to $50 \mathrm{~kg}$ & - & - & - \\
\hline 20 & $\begin{array}{l}\text { What schemes are already in place in your local borough } \\
\text { to reduce plastic waste? }\end{array}$ & Varied & - & - & - \\
\hline 21 & $\begin{array}{l}\text { If you were offered an incentive will it motivate you to } \\
\text { recycle? }\end{array}$ & 73.6 & 26.4 & 1.26 & 0.44 \\
\hline 22 & $\begin{array}{l}\text { Do you agree that the reduction in single use plastic } \\
\text { could help reduce plastic waste? }\end{array}$ & Strongly agreed (70.8) & - & 1.43 & 0.78 \\
\hline 23 & $\begin{array}{l}\text { Would you agree with the government to ban the use of } \\
\text { microbeads in beauty products? }\end{array}$ & Strongly agreed (62.5) & - & 1.76 & 1.09 \\
\hline 24 & $\begin{array}{l}\text { Do you think that charging people for using a single use } \\
\text { plastic bag is efficient in reducing plastic waste? }\end{array}$ & 54.2 & 45.8 & 1.46 & 0.5 \\
\hline 25 & $\begin{array}{l}\text { Would you like your local authorities to implement more } \\
\text { stringent measures for more qualitative plastic waste } \\
\text { recycling? }\end{array}$ & 81.9 & 18.1 & 1.18 & 0.38 \\
\hline 26 & What is your gender? & $\begin{array}{c}\text { Female (68.1) } \\
\text { Male (29.2) } \\
\text { Do not wish to answer (2.8) }\end{array}$ & & 1.74 & 0.5 \\
\hline 27 & Which age group do you belong? & $\begin{array}{l}25-34(22.2 \%) \\
35-44(41.7 \%) \\
45-54(23.6 \%)\end{array}$ & & 2.99 & 0.98 \\
\hline 28 & What is your ethnicity? & $\begin{array}{c}\text { Black (69.4) } \\
\text { White (19.4) } \\
\text { Asian (5.6) } \\
\text { Mixed (5.6) }\end{array}$ & & 6.86 & 2.92 \\
\hline 29 & What is your level of education? & $\begin{array}{c}\text { None (1.4) } \\
\text { Secondary Education(1,4) } \\
\text { Further Education(9.7) } \\
\text { Higher Education(87.5) }\end{array}$ & & 3.83 & 0.5 \\
\hline
\end{tabular}




\begin{tabular}{|c|c|c|c|c|}
\hline 30 & $\begin{array}{l}\text { In which academic discipline does your education } \\
\text { pathway falls into? }\end{array}$ & $\begin{array}{c}\text { Engineering (9.7) } \\
\text { Humanity (20.8) } \\
\text { Science (30.6) } \\
\text { Others (38.9) }\end{array}$ & 2.67 & 1.19 \\
\hline 31 & How many people are in your household? & $\begin{array}{c}\text { One (9.7) } \\
\text { Two (15.3) } \\
\text { Three (23.6) } \\
\text { Four (31.9) } \\
\text { Five (9.7) } \\
\text { More than } 5 \text { (9.7) }\end{array}$ & 3.46 & 1.38 \\
\hline 32 & $\begin{array}{l}\text { Which range would you consider your income to be per } \\
\text { year? }\end{array}$ & $\begin{array}{c}>£ 10000(9.7 \%) \\
£ 10000-£ 14000(9.7 \%) \\
£ 15000-£ 19000(5.6 \%) \\
£ 20000-£ 24000(12.5 \%) \\
£ 25000-£ 29000(19.4 \%) \\
£ 30000-£ 34000(6.9 \%) \\
£ 35000-£ 39000(5.6 \%) \\
£ 40000 \text { and above }(30.6 \%)\end{array}$ & 5.18 & 2.41 \\
\hline
\end{tabular}

A. The Demographics: There were 72 respondents, $68.1 \%$ women mostly from the black and black British backgrounds (Figure 1) and of the age range 35 to 44 years (41.7\%). The latter was consistent with the mean age of people in the WRAP (2019) study which assessed whether consumer awareness of plastic litter has changed since their study in $2012.87 .5 \%$ of the participants have reached higher education with the majority in other disciplines followed by $30.6 \%$ (22 participants) having a scientific background. The households have between 3 to 4 people (55.5\%) with the majority earning above $£ 30000$ a year of which more than $2 / 3$ earning above $£ 40000$ a year (30.6\% of participants).

B. Awareness of Micro-nanoplastics and Behaviour on the use of Plastic Bags: Surprisingly, 77.8\% and 56.9\% (Table 1) of the participants were aware of microplastics and nanoplastics. The news and TV documentaries are the main information sources, mirroring the findings by Anderson, et al. [15] and Henderson and Green [29]. 42\% of participants knew the origin of microplastics and nanoplastics and $82 \%$ participants cited the ocean and beauty products as the major sources (Figure 3). Other sources mentioned were plastic bottles and packaging. In fact, a participant quoted that "I think they originate from either toiletries or are created via the attrition of plastic waste, then get into the ocean and then from there into sea life and the food chain thus, all of the options". 86.1\% of the participants (62) said that they are using products containing microbeads with $50 \%$ of the participants having about 5 or more items in their cupboards, which is very similar to Chang's [37] result, on the usage of facial exfoliating products by students.

It was also found that $91.7 \%$ of the participants reuse bags for shopping, with $66.7 \%$ of the respondents supporting the complete removal of plastic bags and packaging from supermarket shelves and their replacement with bags made from eco-friendly, biodegradable and compostable materials such as cotton, paper and jute. $72.2 \%$ of respondents are happy to pay more for their product if the packaging was biodegradable and if it helps the environment and the product is still affordable. It was also suggested that 'bring your own container' can be used for non- packaged products. However, the role of packaging in product integrity and shelf-life cannot be dismissed. The respondents by $70.8 \%$ strongly agree that the reduction in single use plastics could help reduce plastic waste and $54.2 \%$ think the government charge for single use plastics bags does also help and argued that the 5-p charge is not high enough as a deterrent. These are in line with the finding that majority of consumer preferred $100 \%$ biodegradable packaging WRAP (2019). The deterrents suggested are increasing price increment of the plastic bags and the adoption of the use of biodegradable bags as best practice by manufacturers and retailers. Friedrich, et al. [58] showed that this approach would not lead to price increment and quality reduction.

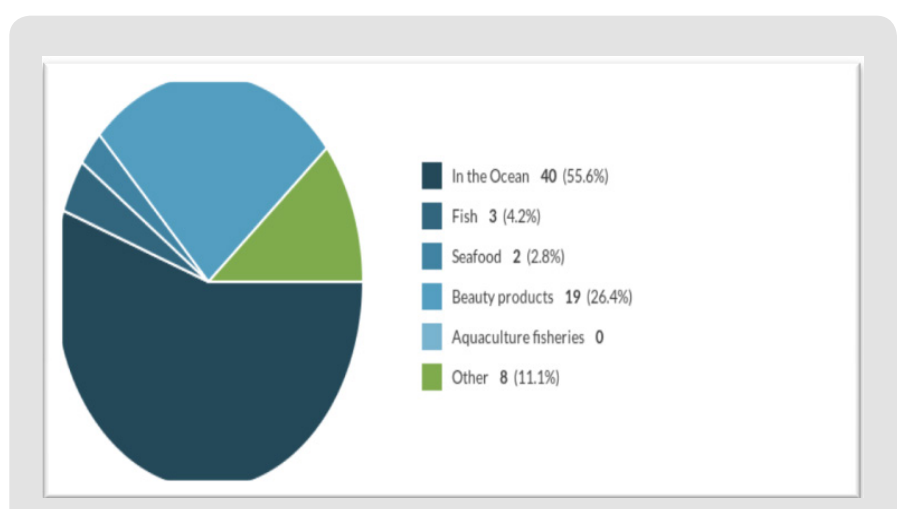

FIGURE 3: The perceived sources of microplastics and nanoplastics. 
C. Management of Waste at Local Authority level: $94.4 \%$ of the participants do recycle their plastic wastes but in majority are not able to estimate the amount of plastic waste they generate, nor the amount collected by their local authority. However, over $50 \%$ are aware of the recycling schemes and initiatives including the provision of dedicated bins and compostable bags. Another opinion on the question suggests that motivation is always a good thing, but it should be the people's obligation to recycle not just their good will.

D. Consumption of Seafood and Food Safety: The literature presented a strong evidence for the presence of microplastics in the tissues of seafood and fish $[16,33,59,60]$ and speculated on the potential risk to human through consumption. The risk may be insignificant as our study showed that $86.1 \%$ of respondents (62) ate little amount of seafood and the consumption is infrequent. However over $80 \%$ believed that food can be contaminated with micro- and nanoplastics and that these particles can be toxic and /or can carry toxic materials. Thus, the food safety concern of microplastics and nanoplastics remains heightened and may trigger changes in seafood consumption [41].

\section{Conclusion}

The overall impression is that the consumers are very much aware of the topical issue of plastic litter and pollution but not so much aware of microplastics nor nano plastic as these are generally invisible. This may hinder the consumer's perception of their environmental and food safety threats as Anderson, et al. [15] stated, that if the consumer cannot visualise the issue, they cannot act, thus the necessity for more consumer awareness campaign. A similar observation was made by Chang [37] who showed that consumers are ready to change their behaviour after being aware of the issue. This was also demonstrated in this survey as it showed a good level of awareness amongst the participants who are already making changes but require more support from the local authorities, the retail industry and other stakeholders. The awareness led the participants to suggest that the solution would be a complete ban of single use plastic or raising awareness and encouraging people to reuse single use plastic where possible several times and then recycle.

Additionally, introduction of more stringent measures by local authorities favoured by a majority of $81.9 \%$. The overall sentiment that comes from their comments is that more public advertisements are needed, all stakeholders need to take their responsibilities $[61,66]$ and incentive based on rent or council tax reduction should be introduced to motivate people to effectively recycle. The threat posed by micro-nano plastics can be extrapolated from the high level of awareness of the environmental threat of plastics, but the question of the potential food safety threat remains. There is also a sense that the level of awareness could be related to level of education as most respondents have reached higher education, but it was not possible to statistically prove it.

\section{Conflicts of Interest}

There is none as the research is not funded by any external body.

\section{Acknowledgements}

The research was carried out at London South Bank University. The authors would like to acknowledge the technical support of $\mathrm{Mr}$ Ken Unadkat and Mr William Cheung.

\section{Highlights}

a. The level of awareness of microplastics and nanoplastics were $77.8 \%$ and $56.9 \%$ respectively.

b. $\quad 82 \%$ participants cited the ocean and beauty products as the major sources of microplastics and nanoplastics.

c. There was a strong evidence for the presence of microplastics in the tissues of seafood and fish, but the risk may be insignificant as $86.1 \%$ of respondents ate little amount of seafood and the consumption is infrequent.

d. The level of awareness of microplastics and nanoplastics is positively linked with the participants' education and income.

e. $\quad 69.4 \%$ of the participants $(n=72)$ were of black ethnicity.

f. The participants' support for plastic reduction schemes were overwhelmingly favourable.

\section{References}

1. (2017) Blue planet II. Episode 7, Our blue planet [Television] Directed by Will Ridgeon, Orla Doherty, Mark Brownlow, and David Attenborough. London: BBC Worldwide.

2. Thompson RC (2015) Microplastics in the marine environment: sources, consequences and solutions. Springer, Cham pp. 185-200.

3. Koelmans AA, Besseling E, Shim WJ (2015) Nanoplastics in the Aquatic Environment. Critical Review. Marine Anthropogenic Litter. Springer International Publishing pp. 325-340.

4. Ferreira I, Venâncio C, Lopes I, Oliveira M (2019) Nanoplastics and marine organisms: What has been studied? Environmental Toxicology and Pharmacology, 67: 1-7.

5. Farady SE (2019) Microplastics as a new, ubiquitous pollutant: Strategies to anticipate management and advise seafood consumers, Marine Policy, 104: 103-107.

6. De-la-Torre GE (2019) Microplastics: An emerging threat to food security and human health. Journal of Food Science and Technology, 57 (2020): 1601-1608.

7. Børresen T (2015) Microplastics-A new threat to aquatic food safety? Journal of Aquatic Food Product Technology 24 (5): 415-416.

8. Cox KD, Covernton GA, Davies HL, Dower JF, Juanes F, et al. (2019) Human consumption of microplastics, Environmental Science \& Technology, 53 (12): 7068-7074. 
9. Chang X, Xue Y, Li J, Zou L, Tang M (2020) Potential health impact of environmental micro- and nanoplastics pollution, Journal of Applied Toxicology, 40 (1): 4-15.

10. Hogstrand C (2016) Presence of microplastics and nanoplastics in food, with particular focus on seafood. Efsa Journal 14 (6): e04501.

11. Li J, Yang D, Li L, Jabeen K, Shi H (2015) Microplastics in commercial bivalves from china. Environmental Pollution 207 (2015): 190-195.

12. Santillo D, Miller K, Johnston P (2017) Microplastics as contaminants in commercially important seafood species. Integrated Environmental Assessment and Management 13 (3): 516-521.

13. Naji A, Nuri M, Vethaak AD (2018) Microplastics contamination in molluscs from the northern part of the Persian gulf, Environmental Pollution 235: 113-120.

14. Rainieri S, Barranco A (2019) Microplastics, a food safety issue? Trends in Food Science \& Technology 84: 55-57.

15. Anderson AG, Grose J, Pahl S, Thompson RC, Wyles KJ, et al. (2016) Microplastics in personal care products: Exploring perceptions of environmentalists, beauticians and students, Marine Pollution Bulletin. 113 (1-2): 454-460.

16. Akhbarizadeh R, Moore F, Keshavarzi B (2019) Investigating microplastics bioaccumulation and biomagnification in seafood from the Persiangulf: A threat to human health? Food Additives \& Contaminants. Part A, Chemistry, Analysis, Control, Exposure \& Risk Assessment. 36(11): 1696-1708.

17. Yurtsever M (2019) Tiny, shiny, and colourful microplastics: Are regular glitters a significant source of microplastics? Marine Pollution Bulletin, 146: 678-682.

18. Rios Mendoza LM, Karapanagioti H, Álvarez NR (2018) Micro(nanoplastics) in the marine environment: Current knowledge and gaps. Current Opinion in Environmental Science \& Health 1: 47-51.

19. Barría C, Brandts I, Tort L, Oliveira M, Teles M, et al. (2020) Effect of nanoplastics on fish health and performance: A review, Marine Pollution Bulletin, 151: 110791.

20. Walkinshaw $C$, Lindeque $P K$, Thompson $R$, Tolhurst $T$, Cole $M$, et al. (2020) Microplastics and seafood: Lower trophic organisms at highest risk of contamination. Ecotoxicology and Environmental Safety 190: 110066.

21. Andrady AL (2017) The plastic in microplastics: A review, Marine Pollution Bulletin, 119 (1): 12-22.

22. Almeida M, Martins MA, Soares AMV, Cuesta A, Oliveira M, et al (2019) Polystyrene nanoplastics alter the cytotoxicity of human pharmaceuticals on marine fish cell lines, Environmental Toxicology and Pharmacology, 69: 57-65.

23. Galloway TS (2015) Micro- and Nano-plastics and Human Health. 1st ed. Springer International Publishing, pp. 343-366.

24. Hu D, Shen M, Zhang Y, Li H, Zeng G, et al. (2019) Microplastics and nanoplastics: Would they affect global biodiversity change? Environmental Science and Pollution Research 26 (19): 19997-20002.

25. Shen M, Zhang Y, Zhu Y, Song B, Zeng G, et al. (2019) Recent advances in toxicological research of nanoplastics in the environment: A review. Environmental Pollution 252 (Pt A): 511-521.

26. Van Cauwenberghe L, Janssen CR (2014) Microplastics in bivalves cultured for human consumption. Environmental Pollution 193: 65-70.

27. Hernandez LM, Xu EG, Larsson HC, Tahara R, Maisuria VB, et al. (2019) Plastic teabags release billions of microparticles and nanoparticles into tea. Environmental Science \& Technology 53 (21): 12300-12310.

28. Li J, Green C, Reynolds A, Shi H, Rotchell JM, et al. (2018) Microplastics in mussels sampled from coastal waters and supermarkets in the united kingdom, Environmental Pollution 241 (2018): 35-44.
29. Henderson L, Green C (2020) Making sense of microplastics? public understandings of plastic pollution, Marine Pollution Bulletin 152 . 110908.

30. Geyer R, Jambeck JR, Law KL (2017) Production, use, and fate of all plastics ever made, Science Advances 3 (7): e1700782.

31. Oni BA, Ayeni AO, Agboola O, Oguntade T, Obanla O, et al. (2020) Comparing microplastics contaminants in (dry and raining) seasons for ox- bow lake in Yenagoa, Nigeria, Ecotoxicology and Environmental Safety $198: 110656$

32. Sökmen TÖ, Sulukan E, Türkoğlu M, Baran A, Özkaraca M, et al. (2020) Polystyrene nanoplastics $(20 \mathrm{~nm})$ are able to bioaccumulate and cause oxidative DNA damages in the brain tissue of zebrafish embryo (danio rerio), Neurotoxicology 77: 51-59.

33. Horn DA, Granek EF, Steele CL (2020) Effects of environmentally relevant concentrations of microplastic fibres on pacific mole crab (emerita analoga) mortality and reproduction. Limnology and Oceanography Letters 5 (1): 74-83

34. Kutralam-Muniasamy G, Pérez-Guevara F, Elizalde-Martínez I, Shruti VC (2020) Branded milks - are they immune from microplastics contamination? Science of the Total Environment 714: 136823.

35. Tong H, Jiang Q, Hu X, Zhong X (2020) Occurrence and identification of microplastics in tap water from china, Chemosphere 252: 126493.

36. Al-Sid-Cheikh M, Rowland SJ, Stevenson K, Rouleau C, Henry TB, et al. (2018) Uptake, whole-body distribution, and depuration of nanoplastics by the scallop pecten maximus at environmentally realistic concentrations, Environmental Science \& Technology 52 (24): 1448014486.

37. Chang M (2015) Reducing microplastics from facial exfoliating cleansers in wastewater through treatment versus consumer product decisions, Marine Pollution Bulletin 101 (1): 330-333.

38. Peberdy E, Jones A, Green D (2019) A study into public awareness of the environmental impact of menstrual products and product choice, Sustainability 11 (2): 473

39. WRAP UK (2019) Plastics Market Situation Report 2019 | WRAP UK.

40. Dilkes-Hoffman L, Ashworth P, Laycock B, Pratt S, Lant P, et al. (2019) Public attitudes towards bioplastics - knowledge, perception and end-of-life management, Resources, Conservation and Recycling, 151: 104479.

41. Jacobs S, Sioen I, Marques A, Verbeke W (2018) Consumer response to health and environmental sustainability information regarding seafood consumption. Environmental Research 161: 492-504.

42. McNicholas G, Cotton M (2019) Stakeholder perceptions of marine plastic waste management in the united kingdom. Ecological Economics 163: 77-87.

43. Willis K, Maureaud C, Wilcox C, Hardesty BD (2018) How successful are waste abatement campaigns and government policies at reducing plastic waste into the marine environment? Marine Policy, 96: 243-249.

44. (2020) FDA The Microbead-Free Waters Act: FAQs.

45. GOV UK (2018) World leading microbeads ban comes into force.

46. (2020) Food Standards Agency 2020. A critical review of microbiological colonisation of nano- and microplastics (Nmicroplasics) and their significance to the food chain.

47. Kish RJ (2018) Using legislation to reduce one-time plastic bag usage. Economic Affairs 38 (2): 224-239.

48. WRAP (2019) Citizens' attitudes \& behaviours relating to food waste, packaging and plastic packaging | WRAP UK.

49. Macauley C (2020) Plastic bag tax raises $£ 2 \mathrm{~m}$ for NI environment. 
50. Maye D, Kirwan J, Brunori G (2019) Ethics and responsibilisation in agri-food governance: The single-use plastics debate and strategies to introduce reusable coffee cups in UK retail chains. Agriculture and Human Values 36 (2): 301-312.

51. Smith L (2020) Plastic waste.

52. GOV UK (2020) The Environmental Protection (Plastic Straws, Cotton Buds and Stirrers) (England) Regulations 2020.

53. Martinho G, Balaia N, Pires A (2017) The Portuguese plastic carrier bag tax: The effects on consumers' behaviour. Waste Management, 61: 3-12.

54. Adam I, Walker TR, Bezerra JC, Clayton A, (2020) Policies to reduce single-use plastic marine pollution in West Africa, Marine Policy, 116 (2020): 103928.

55. Macintosh A, Simpson A, Neeman T, Dickson K (2020) Plastic bag bans: Lessons from the Australian capital territory, Resources. Conservation and Recycling, 154 (2019): 104638.

56. Wearth London (2020) Best Zero Waste Stores in London and Beyond in the UK | Eco Inspo.

57. Office for National Statistics's (2019). UK Analysis of average income.

58. Friedrich D (2020) How regulatory measures towards biobased packaging influence the strategic behaviour of the retail industry: A micro empirical study. Journal of Cleaner Production, 260: 121128.

59. Barboza LGA, Lopes C, Oliveira P, Bessa F, Otero V, et al. (2019) Microplastics in wild fish from north east Atlantic ocean and its potential

ISSN: 2574-1241

DOI: 10.26717/BJSTR.2020.31.005064

Delia Ojinnaka. Biomed J Sci \& Tech Res

(C) This work is licensed under Creative

Submission Link: https://biomedres.us/submit-manuscript.php for causing neurotoxic effects, lipid oxidative damage, and human health risks associated with ingestion exposure, Science of the Total Environment. 717 (2020): pp. 134625.

60. Giani D, Baini M, Galli M, Casini S, Fossi MC, et al. (2019) Microplastics occurrence in edible fish species (Mullus barbatus and Merluccius merluccius) collected in three different geographical sub-areas of the Mediterranean sea, Marine Pollution Bulletin, 140: 129-137.

61. Bonanno G, Orlando-Bonaca M (2018) Ten inconvenient questions about plastics in the sea, Environmental Science and Policy. 85:146-154.

62. Barrows APW, Cathey SE, Petersen C W (2018) Marine environment microfiber contamination: Global patterns and the diversity of microparticle origins, Environmental Pollution. 237 (2018): 275-284.

63. Chae Y, Kim D, Kim SW, An Y (2018) Trophic transfer and individual impact of nano-sized polystyrene in a four-species freshwater food chain. Scientific Reports 8 (1): 1-11.

64. Gu Y, Ning J, Ke C, Huang H (2018) Bioaccessibility and human health implications of heavy metals in different trophic level marine organisms: A case study of the south china sea. Ecotoxicology and Environmental Safety 163: 551-557.

65. Praveena SM, Shaifuddin SNM, Akizuki S (2018) Exploration of microplastics from personal care and cosmetic products and its estimated emissions to marine environment: An evidence from Malaysia, Marine Pollution Bulletin 136: 135-140.

66. Vizard S (2019) Coca-Cola uses new campaign to encourage more people to recycle. Marketing Week, -09-22T23:01:41+00:00

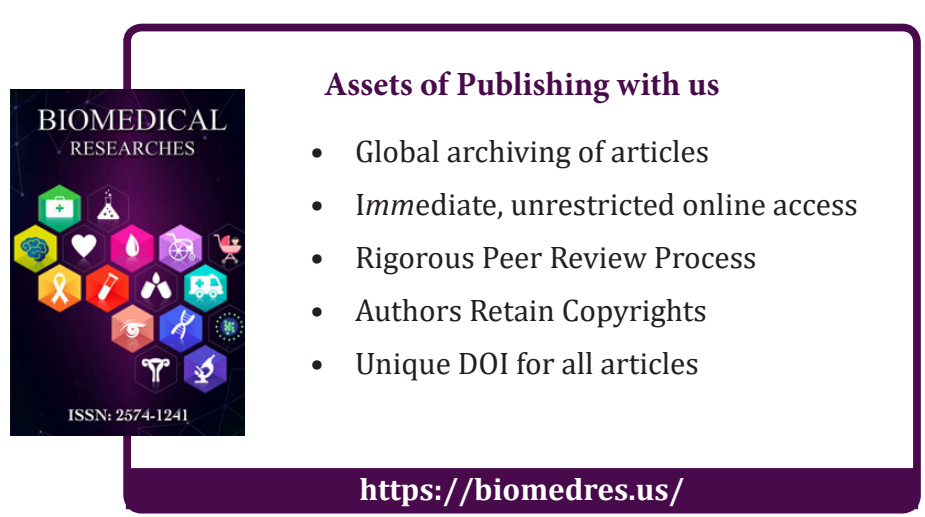

